\title{
Sulindac Sulfide - Induced Stimulation of Eryptosis
}

\author{
Mohanad Zbidah Adrian Lupescu Wenting Yang Anastasia Bosc Kashif Jilani \\ Nazneen Shaik Florian Lang
}

Department of Physiology, University of Tuebingen, Tuebingen

\section{Key Words}

Phosphatidylserine $\cdot$ Sulindac sulfide $\cdot$ Calcium $\bullet$ Cell volume $\bullet$ Ceramide $\bullet$ Eryptosis

\begin{abstract}
Background: Sulindac sulfide, a non-steroidal anti-inflammatory drug (NSAID), stimulates apoptosis of tumor cells and is thus effective against malignancy. In analogy to apoptosis of nucleated cells, erythrocytes may undergo eryptosis, an apoptosislike suicidal erythrocyte death, characterized by cell shrinkage and cell membrane scrambling with phosphatidylserine-exposure at the cell surface. Stimulators of eryptosis include increase of cytosolic $\mathrm{Ca}^{2+}$-activity $\left(\left[\mathrm{Ca}^{2+}\right]_{\mathrm{i}}\right)$ and ceramide formation. The present study explored, whether sulindac sulfide stimulates eryptosis. Methods: $\left[\mathrm{Ca}^{2+}\right]_{i}$ was estimated from Fluo-3 fluorescence, cell volume from forward scatter, phosphatidylserine-exposure from binding of fluorescent annexin- $V$, hemolysis from hemoglobin release, and ceramide abundance utilizing fluorescent antibodies. Results: A $48 \mathrm{~h}$ exposure to sulindac sulfide $(\leq 20$ $\mu \mathrm{M})$ was followed by significant increase of $\left[\mathrm{Ca}^{2+}\right]_{i}$, enhanced ceramide abundance, decreased forward scatter and increased percentage of annexin-V-binding erythrocytes. Sulindac sulfide triggered slight but significant hemolysis. Removal of extracellular $\mathrm{Ca}^{2+}$ significantly blunted, but did not abrogate the effect of sulindac sulfide $(20 \mu \mathrm{M})$ on annexin-V-binding. Conclusion: Sulindac sulfide stimulates the suicidal death of erythrocytes or eryptosis, an effect paralleled by $\mathrm{Ca}^{2+}$-entry, ceramide formation, cell shrinkage and phosphatidylserine-exposure.
\end{abstract}




\section{Introduction}

Sulindac, a non-steroidal anti-inflammatory drug (NSAID) is used for the treatment of pain and a wide variety of inflammatory disorders [1]. Moreover, sulindac has been shown to counteract malignancy [2-9], an effect attributed at least in part to stimulation of apoptosis [9-15]. Mechanisms considered to participate in stimulation of tumor cell apoptosis by sulindac include altered regulation of gene expression [9, 16-19]. On the other hand, sulindac may induce apoptosis of tumor cells by increasing cytosolic $\mathrm{Ca}^{2+}$ activity $\left(\left[\mathrm{Ca}^{2+}\right]_{\mathrm{i}}\right)[13]$.

An increase of $\left[\mathrm{Ca}^{2+}\right]_{i}$ is similarly able to trigger eryptosis, the suicidal death of erythrocytes, which is characterized by cell membrane scrambling and cell shrinkage [20]. In erythrocytes $\left[\mathrm{Ca}^{2+}\right]_{\mathrm{i}}$ may be increased by $\mathrm{Ca}^{2+}$ entry through $\mathrm{Ca}^{2+}$-permeable cation channels $[21,22]$. Cytosolic $\mathrm{Ca}^{2+}$ concentration activates $\mathrm{Ca}^{2+}$-sensitive $\mathrm{K}^{+}$channels [23] leading to $\mathrm{K}^{+}$ exit, hyperpolarization, $\mathrm{Cl}^{-}$exit and thus cellular $\mathrm{KCl}$ loss together with osmotically obliged water, which results in cell shrinkage [24]. Cytosolic $\mathrm{Ca}^{2+}$ further triggers cell membrane scrambling with phosphatidylserine exposure at the cell surface [25]. The $\mathrm{Ca}^{2+}$ sensitivity of erythrocyte cell membrane scrambling is enhanced by ceramide, which similarly stimulates eryptosis [26]. Eryptosis is further triggered by energy depletion [27] and activation of caspases [28-32]. Eryptosis is modified by AMP activated kinase AMPK [22], cGMP-dependent protein kinase [33] and Janus-activated kinase JAK3 [34].

Phosphatidylserine exposed at the erythrocyte surface binds to endothelial CXCL16/ SR-PSO leading to adherence of eryptotic cells to endothelial cells [35]. The adhesion of phosphatidylserine exposing erythrocytes to the vascular wall interferes with microcirculation [35-40]. Phosphatidylserine exposing erythrocytes further foster blood clotting [36, 41, 42]. Accordingly, excessive eryptosis may lead to thrombosis. Moreover, the rapid clearance of erythrocytes from circulating blood may lead to anemia [20]. Accordingly, substances triggering eryptosis could, at least in theory, trigger thrombosis on the one hand, and anemia on the other. Sulindac has indeed been reported to trigger anemia [43]. Whether or not the anemia was secondary to suicidal erythrocyte death, has, however, remained elusive.

The present study thus explored, whether sulindac sulfide increases erythrocyte $\left[\mathrm{Ca}^{2+}\right]_{\mathrm{i}}$ and elicits eryptosis.

\section{Materials and Methods}

\section{Erythrocytes, solutions and chemicals}

Leukocyte-depleted erythrocytes were kindly provided by the blood bank of the University of Tübingen. The study is approved by the ethics committee of the University of Tübingen $(184 / 2003 V)$. Erythrocytes were incubated in vitro at a hematocrit of $0.4 \%$ ( $4 \mu \mathrm{l}$ ) in $1 \mathrm{ml}$ of Ringer solution containing (in mM) $125 \mathrm{NaCl}$, $5 \mathrm{KCl}, 1 \mathrm{MgSO}_{4}, 32 \mathrm{~N}$-2-hydroxyethylpiperazine-N-2-ethanesulfonic acid (HEPES), 5 glucose, $1 \mathrm{CaCl}_{2} ; \mathrm{pH} 7.4$ at $37^{\circ} \mathrm{C}$ for $48 \mathrm{~h}$. Where indicated, erythrocytes were exposed to sulindac sulfide (Enzo, Lörrach, Germany), dissolved in DMSO solution at the indicated concentrations. In $\mathrm{Ca}^{2+}$-free Ringer solution, $1 \mathrm{mM} \mathrm{CaCl}{ }_{2}$ was substituted by $1 \mathrm{mM}$ glycol-bis(2-aminoethylether)-N,N,N',N'-tetraacetic acid (EGTA).

\section{FACS analysis of annexin-V-binding and forward scatter}

After incubation under the respective experimental condition, $50 \mu \mathrm{l}$ cell suspension was washed in Ringer solution containing $5 \mathrm{mM} \mathrm{CaCl}_{2}$ and then stained with Annexin-V-FITC (1:200 dilution; ImmunoTools, Friesoythe, Germany) in this solution at $37^{\circ} \mathrm{C}$ for 20 min under protection from light. In the following, the forward scatter (FSC) of the cells was determined, and annexin-V fluorescence intensity was measured in FL-1 with an excitation wavelength of $488 \mathrm{~nm}$ and an emission wavelength of $530 \mathrm{~nm}$ on a FACS Calibur (BD, Heidelberg, Germany).

Measurement of intracellular $\mathrm{Ca}^{2+}$

To determine intracellular $\mathrm{Ca}^{2+}$, erythrocytes were incubated in vitro at a hematocrit of $0.4 \%(4 \mu \mathrm{L})$ in $1 \mathrm{~mL}$ of Ringer solution containing (in $\mathrm{mM}$ ) $125 \mathrm{NaCl}, 5 \mathrm{KCl}, 1 \mathrm{MgSO}_{4}, 32 \mathrm{~N}$-2-hydroxyethylpiperazine-N-2- 
ethanesulfonic acid (HEPES), 5 glucose, $1 \mathrm{CaCl}_{2} ; \mathrm{pH} 7.4$ at $37^{\circ} \mathrm{C}$ for $48 \mathrm{~h}$. After incubation erythrocytes were washed in Ringer solution and then loaded with Fluo-3/AM (Biotium, Hayward, USA) in Ringer solution containing $5 \mathrm{mM} \mathrm{CaCl}_{2}$ and $2 \mu \mathrm{M}$ Fluo-3/AM. The cells were incubated at $37^{\circ} \mathrm{C}$ for $30 \mathrm{~min}$ and washed twice in Ringer solution containing $5 \mathrm{mM} \mathrm{CaCl}{ }_{2}$. The Fluo-3/AM-loaded erythrocytes were resuspended in 200 $\mu$ l Ringer. Then, $\mathrm{Ca}^{2+}$-dependent fluorescence intensity was measured in fluorescence channel FL-1 at an excitation wavelength of $488 \mathrm{~nm}$ and emission wavelengh of $530 \mathrm{~nm}$ by FACS analysis.

\section{Determination of ceramide formation}

For the determination of ceramide, a monoclonal antibody-based assay was used. After incubation with and without sulindac sulfide, cells were stained for $1 \mathrm{~h}$ at $37^{\circ} \mathrm{C}$ with $1 \mu \mathrm{g} / \mathrm{ml}$ anti-ceramide antibody (clone MID 15B4, Alexis, Grünberg, Germany) in PBS containing 0.1\% bovine serum albumin (BSA) at a dilution of 1:5. The samples were washed twice with PBS-BSA. Subsequently, the cells were stained for 30 minutes with polyclonal fluorescein-isothiocyanate (FITC)-conjugated goat anti-mouse IgG and IgM specific antibody (Pharmingen, Hamburg, Germany) diluted 1:50 in PBS-BSA. Unbound secondary antibody was removed by repeated washing with PBS-BSA. The samples were then analyzed by flow cytometric analysis in FL-1.

Ceramide formation was further determined by confocal microscopy. To this end, $20 \mu \mathrm{l}$ aliquots of anti-ceramide antibody treated samples with or without sulindac pretreatment were smeared onto a glass slide, covered with a coverslip and images were subsequently taken on a Zeiss LSM 5 EXCITER confocal laser scanning microscope (Carl Zeiss MicroImaging, Oberkochen, Germany) with a water immersion PlanNeofluar 63/1.3 NA DIC.

\section{Measurement of hemolysis}

For the determination of hemolysis the samples were centrifuged ( $3 \mathrm{~min}$ at $400 \mathrm{~g}$, room temperature) after incubation, and the supernatants were harvested. As a measure of hemolysis, the hemoglobin ( $\mathrm{Hb}$ ) concentration of the supernatant was determined photometrically at $405 \mathrm{~nm}$. The absorption of the supernatant of erythrocytes lysed in distilled water was defined as $100 \%$ hemolysis.

\section{Statistics}

Data are expressed as arithmetic means \pm SD. As indicated in the figure legends, statistical analysis was made using ANOVA with Tukey's test as post-test or $t$ test as appropriate. $n$ denotes the number of different erythrocyte specimens studied. Since different erythrocyte specimens used are differently susceptible to triggers of eryptosis, the same erythrocyte specimens have been used for control and experimental conditions.

\section{Results}

Cytosolic $\mathrm{Ca}^{2+}$ concentration in erythrocytes was estimated from Fluo-3 fluorescence. To this end erythrocytes were loaded with Fluo-3/AM and the Fluo-3 fluorescence determined utilizing flow cytometry (FACS). Exposure of human erythrocytes to sulindac sulfide was followed by an increase of Fluo-3 fluorescence, an effect reaching statistical significance at $5 \mu \mathrm{M}$ sulindac sulfide concentration (Fig. 1). Accordingly, sulindac sulfide increased cytosolic $\mathrm{Ca}^{2+}$ concentration.

Enhanced cytosolic $\mathrm{Ca}^{2+}$ concentrations are known to activate $\mathrm{Ca}^{2+}$-sensitive $\mathrm{K}^{+}$channels resulting in $\mathrm{KCl}$ exit with osmotically obliged water, an effect leading to cell shrinkage. Thus, cell volume was estimated from forward scatter in FACS analysis. As illustrated in Fig. 2, the exposure of human erythrocytes to sulindac sulfide was followed by a decrease of forward scatter, an effect reaching statistical significance at $20 \mu \mathrm{M}$ sulindac sulfide concentration.

Increased cytosolic $\mathrm{Ca}^{2+}$ concentration is further expected to trigger cell membrane scrambling resulting in phosphatidylserine exposure at the cell surface. Thus, additional experiments were performed to identify phosphatidylserine exposing erythrocytes with fluorescent annexin- $V$. The percentage of annexin-V-binding erythrocytes was determined by FACS analysis. As shown in Fig. 3, the percentage of annexin-V-binding erythrocytes increased following a $48 \mathrm{~h}$ exposure to sulindac sulfide. The effect reached statistical significance at 20 $\mu \mathrm{M}$ sulindac sulfide concentration. 


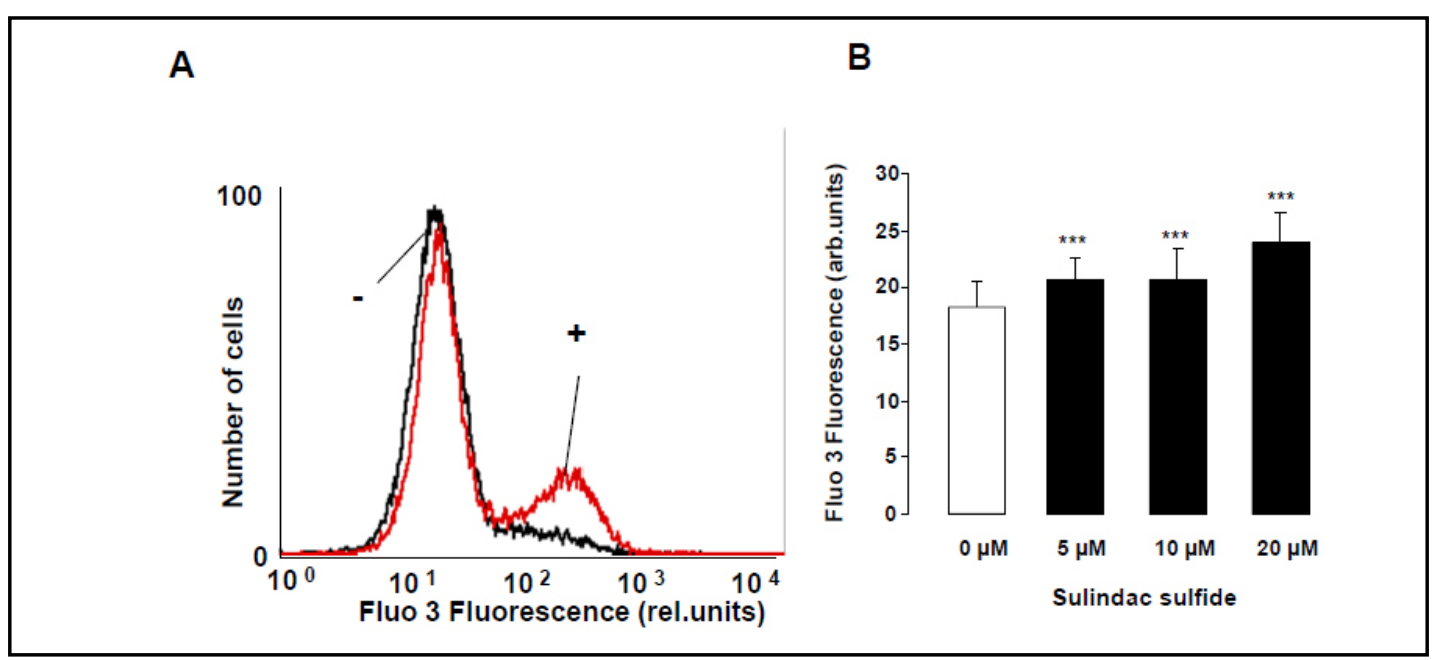

Fig. 1. Effect of sulindac sulfide on erythrocyte cytosolic $\mathrm{Ca}^{2+}$ concentration. A. Original histogram of Fluo-3 fluorescence in erythrocytes following exposure for $48 \mathrm{~h}$ to Ringer solution without (-, black line) and with $(+$, red line $)$ presence of $20 \mu \mathrm{M}$ sulindac sulfide. B. Arithmetic means \pm SD $(n=13)$ of the normalized geo means (geometric mean of the histogram in arbitrary units) of Fluo-3 fluorescence in erythrocytes exposed for $48 \mathrm{~h}$ to Ringer solution without (white bar) or with (black bars) sulindac sulfide $(5-20 \mu \mathrm{M}) .{ }^{* * *}(\mathrm{p}<0.001)$ indicates significant difference from the absence of sulindac sulfide (ANOVA).

A

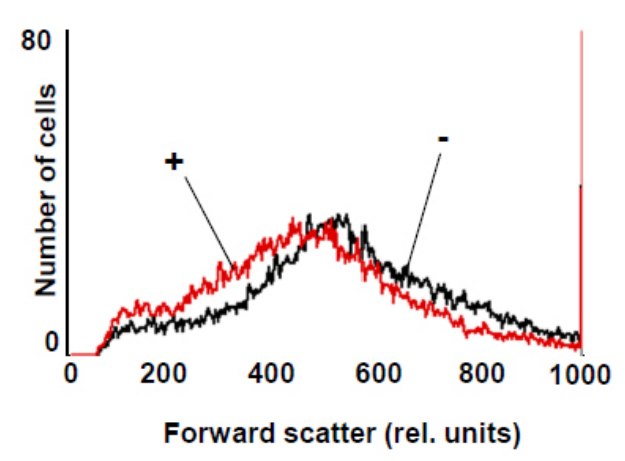

B

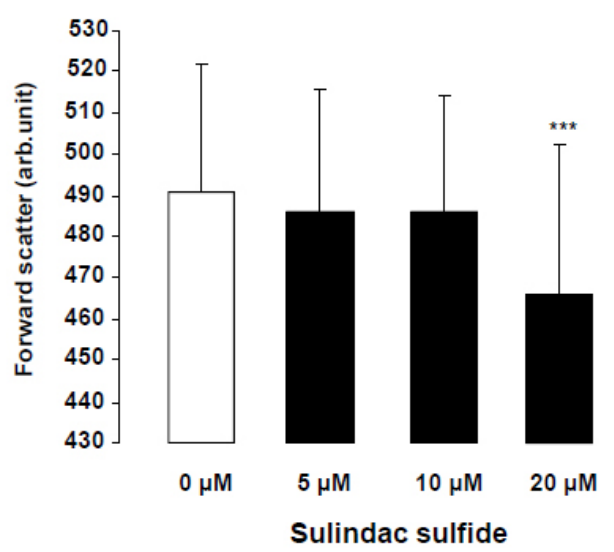

Fig. 2. Effect of sulindac sulfide on erythrocyte forward scatter. A. Original histogram of forward scatter of erythrocytes following exposure for $48 \mathrm{~h}$ to Ringer solution without (-, black line) and with $(+$, red line) presence of $20 \mu \mathrm{M}$ sulindac sulfide. B. Arithmetic means \pm SD $(n=13)$ of the normalized erythrocyte forward scatter (FSC) following incubation for $48 \mathrm{~h}$ to Ringer solution without (white bar) or with (black bars) sulindac sulfide $(5-20 \mu \mathrm{M}){ }^{* * *}(\mathrm{p}<0.001)$ indicates significant difference from the absence of sulindac sulfide (ANOVA).

In an additional series of experiments the effect of sulindac sulfide on hemolysis was estimated from hemoglobin concentration in the supernatant. As illustrated in Fig. 3, exposure of erythrocytes for $48 \mathrm{~h}$ to sulindac sulfide was indeed followed by an increase of the extracellular hemoglobin concentration, an effect reaching statistical significance at 10 $\mu \mathrm{M}$ (Fig. 3 B). The percentage of hemolysed erythrocytes remained, however, one order of magnitude smaller than the percentage of phosphatidylserine exposing cells.

Further experiments aimed to gain some insight into the mechanisms underlying sulindac sulfide induced cell membrane scrambling. A first series of experiments addressed, 
A

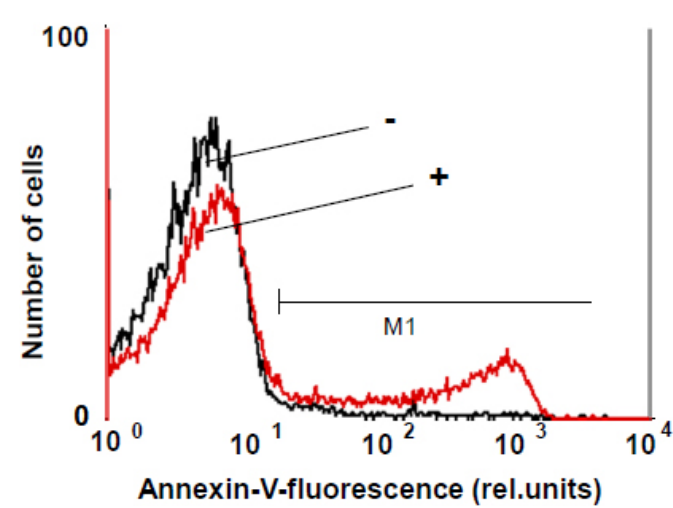

B

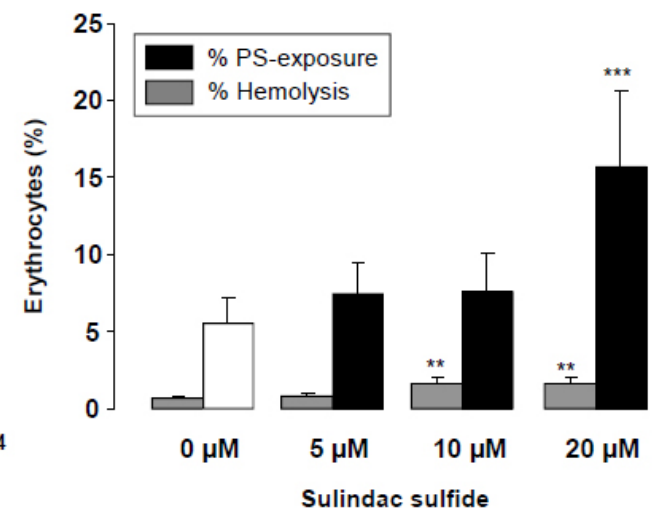

Fig. 3. Effect of sulindac sulfide on phosphatidylserine exposure and hemolysis. A. Original histogram of annexin-V-binding of erythrocytes following exposure for $48 \mathrm{~h}$ to Ringer solution without (-, black line) and with $(+$, red line) presence of $20 \mu \mathrm{M}$ sulindac sulfide. B. Arithmetic means \pm SD of erythrocyte annexin-Vbinding $(n=13)$ following incubation for $48 \mathrm{~h}$ to Ringer solution without (white bar) or with (black bars) presence of sulindac sulfide (5-20 $\mu \mathrm{M})$. For comparison, arithmetic means $\pm \operatorname{SD}(n=4)$ of the percentage of hemolysis is shown as grey bars. ${ }^{* *}(\mathrm{p}<0.01),{ }^{* * *}(\mathrm{p}<0.001)$ indicates significant difference from the absence of sulindac sulfide (ANOVA).

Fig. 4. Effect of $\mathrm{Ca}^{2+}$ withdrawal on sulindac sulfideinduced annexin-V-binding. Arithmetic means \pm $\mathrm{SD}(n=4)$ of the percentage of annexin V-binding erythrocytes after a $48 \mathrm{~h}$ treatment with Ringer solution without (white bar) or with (black bars) $20 \mu \mathrm{M}$ sulindac sulfide in the presence (left bars, $+\mathrm{Ca}^{2+}$ ) and absence (right bars, $-\mathrm{Ca}^{2+}$ ) of calcium. ${ }^{* * *}$ $(\mathrm{p}<0.001)$ indicates significant difference from the absence of sulindac sulfide (ANOVA) \#\#\# ( $\mathrm{p}<0.001)$ indicates significant difference from the respective values in the presence of $\mathrm{Ca}^{2+}$.

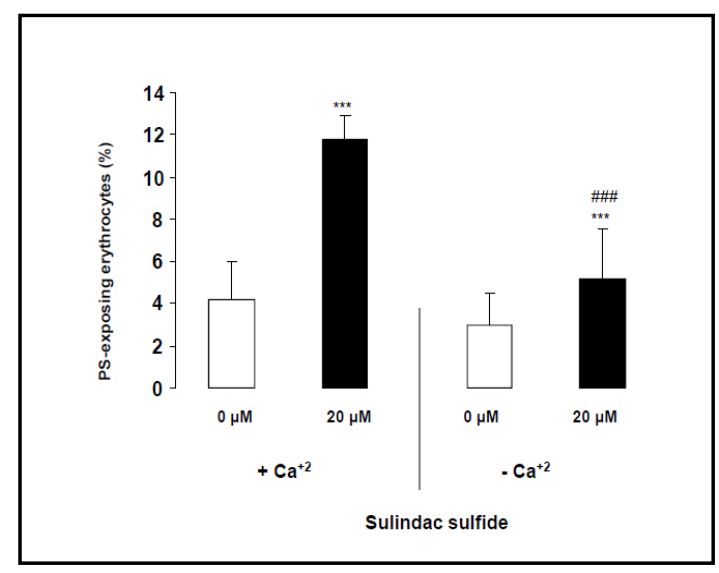

whether the sulindac sulfide induced cell membrane scrambling required $\mathrm{Ca}^{2+}$ entry from the extracellular space. To this end, erythrocytes were exposed to $20 \mu \mathrm{M}$ sulindac sulfide either in the presence or in the nominal absence of extracellular $\mathrm{Ca}^{2+}$. As illustrated in Fig. 4 , the effect of sulindac sulfide on the percentage of annexin-V-binding erythrocytes was significantly blunted in the nominal absence of $\mathrm{Ca}^{2+}$. However, even in the nominal absence of $\mathrm{Ca}^{2+}$, the percentage of annexin-V-binding erythrocytes was significantly higher in the presence than in the nominal absence of extracellular $\mathrm{Ca}^{2+}$. Thus, stimulation of erythrocyte membrane scrambling by sulindac sulfide was in large part but not fully dependent on $\mathrm{Ca}^{2+}$ entry.

As $\mathrm{Ca}^{2+}$ sensitivity of cell membrane scrambling is known to be enhanced by ceramide, additional experiments were performed analysing the effect of sulindac sulfide treatment on ceramide formation. To this end, ceramide abundance at the erythrocyte surface was determined utilizing FITC-labeled anti-ceramide antibodies. As a result, a $48 \mathrm{~h}$ incubation 
A

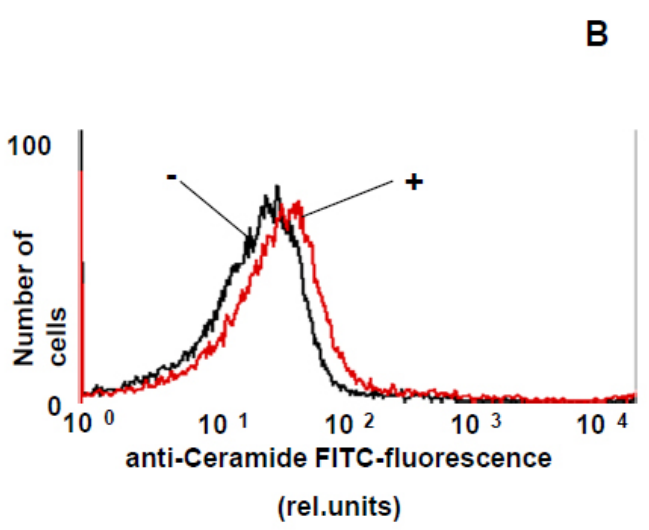

C

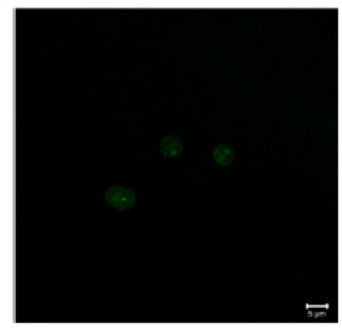

$0 \mu \mathrm{M}$

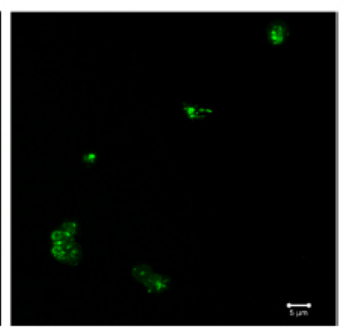

$20 \mu \mathrm{M}$

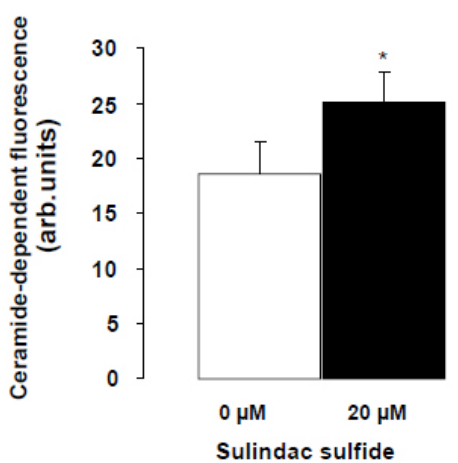

Sulindac sulfide

Fig. 5. Effect of sulindac sulfide on ceramide formation. A. Original histogram of anti-ceramide FITCfluorescence in erythrocytes following exposure for $48 \mathrm{~h}$ to Ringer solution without (-, black line) and with $(+$, red line $)$ presence of sulindac sulfide $(20 \mu \mathrm{M})$. B. Arithmetic means \pm SD $(n=4)$ of ceramide abundance after a $48 \mathrm{~h}$ incubation in Ringer solution without (white bar) or with (black bars) sulindac sulfide (20 $\mu \mathrm{M}){ }^{*}(\mathrm{p}<0.05$ ) indicates significant difference from control (absence of sulindac sulfide) (upaired $t$ test). C. Confocal microscopy of FITC-dependent fluorescence of human erythrocytes stained with anti-ceramide antibody following $48 \mathrm{~h}$ incubation in Ringer solution without (left) and with (right) $20 \mu \mathrm{M}$ sulindac sulfide.

in sulindac sulfide $(20 \mu \mathrm{M})$ significantly increased the ceramide-dependent fluorescence intensity (Fig. 5 B). The increase of ceramide abundance was further apparent from confocal microscopy (Fig. 5 C).

\section{Discussion}

The present study demonstrates that sulindac sulfide increases cytosolic $\mathrm{Ca}^{2+}$ activity $\left(\left[\mathrm{Ca}^{2+}\right]_{\mathrm{i}}\right)$ and triggers eryptosis, the suicidal death of erythrocytes, which is characterized by erythrocyte membrane scrambling and erythrocyte shrinkage. The concentration required for the effect on cell membrane scrambling is in the range of the in vivo plasma concentrations, which may approach some $10 \mu \mathrm{M}$ [44]). The free plasma concentration may be lower due to binding of the substance to plasma protein [45].

Sulindac has previously been shown to increase $\left[\mathrm{Ca}^{2+}\right]_{\mathrm{i}}$ in tumor cells [13]. In erythrocytes, the $\mathrm{Ca}^{2+}$ entry is secondary to activation of non-selective cation channels. The molecular identity of the $\mathrm{Ca}^{2+}$ permeable erythrocyte cation channels has remained enigmatic but apparently does involve the $\mathrm{Ca}^{2+}$ permeable cation channel TRPC6 [21]. The cation channels are sensitive to oxidative stress [46]. The stimulation of $\mathrm{Ca}^{2+}$ entry into erythrocytes parallels a similar phenomenon in tumor cells. In those cells, sulindac induced apoptosis involves, however, 
a complex machinery eventually affecting gene expression [9, 16-19]. As erythrocytes lack nuclei, altered transcription is obviously not required for sulindac-induced suicidal cell death.

As shown earlier $[23,47]$, the increase of cytosolic $\mathrm{Ca}^{2+}$ activity opens $\mathrm{Ca}^{2+}$-sensitive $\mathrm{K}^{+}$channels resulting in subsequent exit of $\mathrm{K}^{+}$following its chemical gradient, cell membrane hyperpolarization and potential driven $\mathrm{Cl}^{-}$exit [20]. The cellular loss of $\mathrm{KCl}$ is accompanied by exit of osmotically obliged water [24] leading to cell shrinkage. Accordingly, sulindac decreases erythrocyte forward scatter. The effect on cell volume is small. Given the high sensitivity of a variety of cellular functions to cell volume, however, this small effect could well be relevant [48].

The increase of cytosolic $\mathrm{Ca}^{2+}$ activity further elicits cell membrane scrambling, which results in phosphatidylserine exposure at the erythrocyte surface $[25,49,50]$. The sulindac-induced cell membrane scrambling is significantly blunted in the nominal absence of extracellular $\mathrm{Ca}^{2+}$, indicating that $\mathrm{Ca}^{2+}$ entry is indeed the major mechanism accounting for sulindac-induced suicidal erythrocyte death. However, removal of extracellular $\mathrm{Ca}^{2+}$ did not fully abrogate the scrambling effect of sulindac sulfide, indicating that sulindac sulfide-induced eryptosis involves additional mechanisms.

One of those mechanisms may be ceramide formation. Sulindac sulfide did increase the formation of ceramide, which sensitizes the erythrocytes for the scrambling effect of increased $\left[\mathrm{Ca}^{2+}\right]_{i}[26,51]$. Ceramide similarly triggers apoptosis of nucleated cells [52]. Ceramide formation participates in the pathophysiology of several clinical disorders, such as lung inflammation, fibrosis and infection [53], cystic fibrosis [54], cardiovascular disease [55, 56], Wilson's disease [57], multiple sclerosis [58], major depression [52], Parkinson's disease [59], Alzheimer's disease [52, 60, 61] and diabetes [62-64].

It should be pointed out that even at higher concentrations, sulindac triggers eryptosis only in a subset of erythrocytes. The effect of sulindac on cytosolic $\mathrm{Ca}^{2+}$, forward scatter, phosphatidylserine exposure and ceramide formation, is not homogeneous, Thus, the erythrocytes are not uniformly sensitive to the drug. The sensitivity of erythrocytes to triggers of eryptosis is influenced by erythrocyte age [65] and presumably less well defined properties of individual erythrocytes.

Similar to sulindac sulfide a wide variety of xenobiotics trigger eryptosis [28, 34, 66-75]. Enhanced eryptosis further contributes to the pathophysiology of several clinical disorders [20], including diabetes [32, 76, 77], renal insufficiency [78], hemolytic uremic syndrome [79], sepsis [80], sickle cell disease [81]. malaria [57, 82-85], Wilson's disease [57], iron deficiency [86], phosphate depletion [87] and presumably metabolic syndrome [88].

In conclusion, sulindac sulfide elicits $\mathrm{Ca}^{2+}$ entry and ceramide formation, effects eventually leading to stimulation of cell membrane scrambling and cell shrinkage. Accordingly, similar to its proapoptotic effect on nucleated cells, sulindac sulfide stimulates eryptosis, the suicidal death of erythrocytes.

\section{Acknowledgements}

The authors acknowledge the meticulous preparation of the manuscript by Lejla Subasic. This study was supported by the Deutsche Forschungsgemeinschaft.

\section{References}

1 Moore RA, Derry S, McQuay HJ: Single dose oral sulindac for acute postoperative pain in adults. Cochrane Database Syst Rev 2009;CD007540. 


\section{Cellular Physiology $\quad$ Cell Physiol Biochem 2012;30:1072-1082 and Biochemistry

-2 Limburg PJ, Mahoney MR, Ziegler KL, Sontag SJ, Schoen RE, Benya R, Lawson MJ, Weinberg DS, Stoffel E, Chiorean M, Heigh R, Levine J, Della'Zanna G, Rodriguez L, Richmond E, Gostout C, Mandrekar SJ, Smyrk TC: Randomized phase II trial of sulindac, atorvastatin, and prebiotic dietary fiber for colorectal cancer chemoprevention. Cancer Prev Res (Phila) 2011;4:259-269.

- Mackenzie GG, Ouyang N, Xie G, Vrankova K, Huang L, Sun Y, Komninou D, Kopelovich L, Rigas B: Phosphosulindac (OXT-328) combined with difluoromethylornithine prevents colon cancer in mice. Cancer Prev Res (Phila) 2011;4:1052-1060.

4 Mladenova D, Daniel JJ, Dahlstrom JE, Bean E, Gupta R, Pickford R, Currey N, Musgrove EA, Kohonen-Corish MR: The NSAID sulindac is chemopreventive in the mouse distal colon but carcinogenic in the proximal colon. Gut 2011;60:350-360.

5 Tinsley HN, Gary BD, Thaiparambil J, Li N, Lu W, Li Y, Maxuitenko YY, Keeton AB, Piazza GA: Colon tumor cell growth-inhibitory activity of sulindac sulfide and other nonsteroidal anti-inflammatory drugs is associated with phosphodiesterase 5 inhibition. Cancer Prev Res (Phila) 2010;3:1303-1313.

6 Wang X, Kingsley PJ, Marnett LJ, Eling TE: The role of NAG-1/GDF15 in the inhibition of intestinal polyps in APC/Min mice by sulindac. Cancer Prev Res (Phila) 2011;4:150-160.

7 Wentz SC, Yip-Schneider MT, Gage EA, Saxena R, Badve S, Schmidt CM: Sulindac prevents carcinogeninduced intrahepatic cholangiocarcinoma formation in vivo. J Surg Res 2009;157:e87-e95.

8 Fujiki H, Suganuma M, Kurusu M, Okabe S, Imayoshi Y, Taniguchi S, Yoshida T: New TNF-alpha releasing inhibitors as cancer preventive agents from traditional herbal medicine and combination cancer prevention study with EGCG and sulindac or tamoxifen. Mutat Res 2003;523-524:119-125.

-9 Haanen C: Sulindac and its derivatives: a novel class of anticancer agents. Curr Opin Investig Drugs 2001;2:677-683.

-10 Stepnik M, Ferlinska M, Smok-Pieniazek A, Gradecka-Meesters D, Arkusz J, Stanczyk M: Sulindac and its metabolites: sulindac sulfide and sulindac sulfone enhance cytotoxic effects of arsenic trioxide on leukemic cell lines. Toxicol In Vitro 2011;25:1075-1084.

11 Lim SJ, Lee E, Lee EH, Kim SY, Cha JH, Choi H, Park W, Choi HK, Ko SH, Kim SH: Docosahexaenoic acid sensitizes colon cancer cells to sulindac sulfide-induced apoptosis. Oncol Rep 2012;27:2023-2030.

12 Liu C, Tsai AL, Chen YC, Fan SC, Huang CH, Wu CC, Chang CH: Facilitation of human osteoblast apoptosis by sulindac and indomethacin under hypoxic injury. J Cell Biochem 2012;113:148-155.

13 Vaish V, Sanyal SN: Role of Sulindac and Celecoxib in chemoprevention of colorectal cancer via intrinsic pathway of apoptosis: Exploring NHE-1, intracellular calcium homeostasis and Calpain 9. Biomed Pharmacother 2012;66:116-130.

14 Jakubowska-Mucka A, Sienko J, Zapala L, Wolny R, Lasek W: Synergistic cytotoxic effect of sulindac and pyrrolidine dithiocarbamate against ovarian cancer cells. Oncol Rep 2012;27:1245-1250.

-15 Jin HO, Yoon SI, Seo SK, Lee HC, Woo SH, Yoo DH, Lee SJ, Choe TB, An S, Kwon TJ, Kim JI, Park MJ, Hong SI, Park IC, Rhee CH: Synergistic induction of apoptosis by sulindac and arsenic trioxide in human lung cancer A549 cells via reactive oxygen species-dependent down-regulation of survivin. Biochem Pharmacol 2006;72:1228-1236.

-16 Tinsley HN, Gary BD, Keeton AB, Lu W, Li Y, Piazza GA: Inhibition of PDE5 by sulindac sulfide selectively induces apoptosis and attenuates oncogenic Wnt/beta-catenin-mediated transcription in human breast tumor cells. Cancer Prev Res (Phila) 2011;4:1275-1284.

17 Li X, Gao L, Cui Q, Gary BD, Dyess DL, Taylor W, Shevde LA, Samant RS, Dean-Colomb W, Piazza GA, Xi Y: Sulindac inhibits tumor cell invasion by suppressing NF-kappaB-mediated transcription of microRNAs. Oncogene 2012; doi: 10.1038/onc.2011.655.

-18 Singh R, Cadeddu RP, Frobel J, Wilk CM, Bruns I, Zerbini LF, Prenzel T, Hartwig S, Brunnert D, Schroeder T, Lehr S, Haas R, Czibere A: The non-steroidal anti-inflammatory drugs Sulindac sulfide and Diclofenac induce apoptosis and differentiation in human acute myeloid leukemia cells through an AP-1 dependent pathway. Apoptosis 2011;16:889-901.

-19 Weidinger C, Krause K, Mueller K, Klagge A, Fuhrer D: FOXO3 is inhibited by oncogenic PI3K/Akt signaling but can be reactivated by the NSAID sulindac sulfide. J Clin Endocrinol Metab 2011;96:E1361-E1371.

-20 Lang F, Gulbins E, Lerche H, Huber SM, Kempe DS, Foller M: Eryptosis, a window to systemic disease. Cell Physiol Biochem 2008;22:373-380.

21 Foller M, Kasinathan RS, Koka S, Lang C, Shumilina E, Birnbaumer L, Lang F, Huber SM: TRPC6 contributes to the $\mathrm{Ca}^{2+}$ leak of human erythrocytes. Cell Physiol Biochem 2008;21:183-192. 


\section{Cellular Physiology $\quad$ Cell Physiol Biochem 2012;30:1072-1082 and Biochemistry

-22 Foller M, Sopjani M, Koka S, Gu S, Mahmud H, Wang K, Floride E, Schleicher E, Schulz E, Munzel T, Lang F: Regulation of erythrocyte survival by AMP-activated protein kinase. FASEB J 2009;23:1072-1080.

23 Brugnara C, de Franceschi L, Alper SL: Inhibition of $\mathrm{Ca}^{2+}$-dependent $\mathrm{K}^{+}$transport and cell dehydration in sickle erythrocytes by clotrimazole and other imidazole derivatives. J Clin Invest 1993;92:520-526.

-24 Lang PA, Kaiser S, Myssina S, Wieder T, Lang F, Huber SM: Role of $\mathrm{Ca}^{2+}$-activated $\mathrm{K}^{+}$channels in human erythrocyte apoptosis. Am J Physiol Cell Physiol 2003;285:C1553-C1560.

-25 Berg CP, Engels IH, Rothbart A, Lauber K, Renz A, Schlosser SF, Schulze-Osthoff K, Wesselborg S: Human mature red blood cells express caspase- 3 and caspase-8, but are devoid of mitochondrial regulators of apoptosis. Cell Death Differ 2001;8:1197-1206.

-26 Lang F, Gulbins E, Lang PA, Zappulla D, Foller M: Ceramide in suicidal death of erythrocytes. Cell Physiol Biochem 2010;26:21-28.

$\checkmark 27$ Klarl BA, Lang PA, Kempe DS, Niemoeller OM, Akel A, Sobiesiak M, Eisele K, Podolski M, Huber SM, Wieder T, Lang F: Protein kinase C mediates erythrocyte "programmed cell death" following glucose depletion. Am J Physiol Cell Physiol 2006;290:C244-C253.

28 Bhavsar SK, Bobbala D, Xuan NT, Foller M, Lang F: Stimulation of suicidal erythrocyte death by alpha-lipoic acid. Cell Physiol Biochem 2010;26:859-868.

29 Foller M, Huber SM, Lang F: Erythrocyte programmed cell death. IUBMB Life 2008;60:661-668.

- 30 Foller M, Mahmud H, Gu S, Wang K, Floride E, Kucherenko Y, Luik S, Laufer S, Lang F: Participation of leukotriene C(4) in the regulation of suicidal erythrocyte death. J Physiol Pharmacol 2009;60:135-143.

31 Lau IP, Chen H, Wang J, Ong HC, Leung KC, Ho HP, Kong SK: In vitro effect of CTAB- and PEG-coated gold nanorods on the induction of eryptosis/erythroptosis in human erythrocytes. Nanotoxicology 2011; [Epub ahead of print].

32 Maellaro E, Leoncini S, Moretti D, Del Bello B, Tanganelli I, De Felice C, Ciccoli L: Erythrocyte caspase-3 activation and oxidative imbalance in erythrocytes and in plasma of type 2 diabetic patients. Acta Diabetol 2011; [Epub ahead of print].

-33 Foller M, Feil S, Ghoreschi K, Koka S, Gerling A, Thunemann M, Hofmann F, Schuler B, Vogel J, Pichler B, Kasinathan RS, Nicolay JP, Huber SM, Lang F, Feil R: Anemia and splenomegaly in cGKI-deficient mice. Proc Natl Acad Sci USA 2008;105:6771-6776.

-34 Bhavsar SK, Gu S, Bobbala D, Lang F: Janus kinase 3 is expressed in erythrocytes, phosphorylated upon energy depletion and involved in the regulation of suicidal erythrocyte death. Cell Physiol Biochem 2011;27:547-556.

-35 Borst O, Abed M, Alesutan I, Towhid ST, Qadri SM, Foller M, Gawaz M, Lang F: Dynamic adhesion of eryptotic erythrocytes to endothelial cells via CXCL16/SR-PSOX. Am J Physiol Cell Physiol 2011; 302:C644651.

-36 Andrews DA, Low PS: Role of red blood cells in thrombosis. Curr Opin Hematol 1999;6:76-82.

-37 Closse C, Dachary-Prigent J, Boisseau MR: Phosphatidylserine-related adhesion of human erythrocytes to vascular endothelium. Br J Haematol 1999;107:300-302.

-38 Gallagher PG, Chang SH, Rettig MP, Neely JE, Hillery CA, Smith BD, Low PS: Altered erythrocyte endothelial adherence and membrane phospholipid asymmetry in hereditary hydrocytosis. Blood 2003;101:46254627.

39 Pandolfi A, Di Pietro N, Sirolli V, Giardinelli A, Di Silvestre S, Amoroso L, Di Tomo P, Capani F, Consoli A, Bonomini M: Mechanisms of uremic erythrocyte-induced adhesion of human monocytes to cultured endothelial cells. J Cell Physiol 2007;213:699-709.

-40 Wood BL, Gibson DF, Tait JF: Increased erythrocyte phosphatidylserine exposure in sickle cell disease: flowcytometric measurement and clinical associations. Blood 1996;88:1873-1880.

41 Chung SM, Bae ON, Lim KM, Noh JY, Lee MY, Jung YS, Chung JH: Lysophosphatidic acid induces thrombogenic activity through phosphatidylserine exposure and procoagulant microvesicle generation in human erythrocytes. Arterioscler Thromb Vasc Biol 2007;27:414-421.

-42 Zwaal RF, Comfurius P, Bevers EM: Surface exposure of phosphatidylserine in pathological cells. Cell Mol Life Sci 2005;62:971-988.

43 Sanford-Driscoll M, Knodel LC: Induction of hemolytic anemia by nonsteroidal antiinflammatory drugs. Drug Intell Clin Pharm 1986;20:925-934.

44 Henrich WL, Brater DC, Campbell WB: Renal hemodynamic effects of therapeutic plasma levels of sulindac sulfide during hemorrhage. Kidney Int 1986;29:484-489. 


\section{Cellular Physiology $\quad$ Cell Physiol Biochem 2012;30:1072-1082 and Biochemistry

45 Davies NM, Watson MS: Clinical pharmacokinetics of sulindac. A dynamic old drug. Clin Pharmacokinet 1997;32:437-459.

46 Brand VB, Sandu CD, Duranton C, Tanneur V, Lang KS, Huber SM, Lang F: Dependence of Plasmodium falciparum in vitro growth on the cation permeability of the human host erythrocyte. Cell Physiol Biochem 2003;13:347-356.

47 Bookchin RM, Ortiz OE, Lew VL: Activation of calcium-dependent potassium channels in deoxygenated sickled red cells. Prog Clin Biol Res 1987;240:193-200.

-48 Lang F, Busch GL, Ritter M, Volkl H, Waldegger S, Gulbins E, Haussinger D: Functional significance of cell volume regulatory mechanisms. Physiol Rev 1998;78:247-306.

-49 Bratosin D, Estaquier J, Petit F, Arnoult D, Quatannens B, Tissier JP, Slomianny C, Sartiaux C, Alonso C, Huart JJ, Montreuil J, Ameisen JC: Programmed cell death in mature erythrocytes: a model for investigating death effector pathways operating in the absence of mitochondria. Cell Death Differ 2001;8:1143-1156.

50 Lang KS, Duranton C, Poehlmann H, Myssina S, Bauer C, Lang F, Wieder T, Huber SM: Cation channels trigger apoptotic death of erythrocytes. Cell Death Differ 2003;10:249-256.

51 Lang KS, Myssina S, Brand V, Sandu C, Lang PA, Berchtold S, Huber SM, Lang F, Wieder T: Involvement of ceramide in hyperosmotic shock-induced death of erythrocytes. Cell Death Differ 2004;11:231-243.

52 Kornhuber J, Tripal P, Reichel M, Muhle C, Rhein C, Muehlbacher M, Groemer TW, Gulbins E: Functional Inhibitors of Acid Sphingomyelinase (FIASMAs): a novel pharmacological group of drugs with broad clinical applications. Cell Physiol Biochem 2010;26:9-20.

-53 Dhami R, He X, Schuchman EH: Acid sphingomyelinase deficiency attenuates bleomycin-induced lung inflammation and fibrosis in mice. Cell Physiol Biochem 2010;26:749-760.

54 Becker KA, Grassme H, Zhang Y, Gulbins E: Ceramide in Pseudomonas aeruginosa infections and cystic fibrosis. Cell Physiol Biochem 2010;26:57-66.

55 Kuebler WM, Yang Y, Samapati R, Uhlig S: Vascular barrier regulation by PAF, ceramide, caveolae, and NO - an intricate signaling network with discrepant effects in the pulmonary and systemic vasculature. Cell Physiol Biochem 2010;26:29-40.

56 Li X, Becker KA, Zhang Y: Ceramide in redox signaling and cardiovascular diseases. Cell Physiol Biochem 2010;26:41-48.

57 Lang PA, Schenck M, Nicolay JP, Becker JU, Kempe DS, Lupescu A, Koka S, Eisele K, Klarl BA, Rubben H, Schmid KW, Mann K, Hildenbrand S, Hefter H, Huber SM, Wieder T, Erhardt A, Haussinger D, Gulbins E, Lang F: Liver cell death and anemia in Wilson disease involve acid sphingomyelinase and ceramide. Nat Med 2007;13:164-170.

58 Walter S, Fassbender K: Spingolipids in Multiple Sclerosis. Cell Physiol Biochem 2010;26:49-56.

-59 Arboleda G, Huang TJ, Waters C, Verkhratsky A, Fernyhough P, Gibson RM: Insulin-like growth factor-1dependent maintenance of neuronal metabolism through the phosphatidylinositol 3-kinase-Akt pathway is inhibited by C2-ceramide in CAD cells. Eur J Neurosci 2007;25:3030-3038.

60 de la Monte SM: Insulin resistance and Alzheimer's disease. BMB Rep 2009;42:475-481.

61 Tong M, Neusner A, Longato L, Lawton M, Wands JR, de la Monte SM: Nitrosamine exposure causes insulin resistance diseases: relevance to type 2 diabetes mellitus, non-alcoholic steatohepatitis, and Alzheimer's disease. J Alzheimers Dis 2009;17:827-844.

-62 Zhao H, Przybylska M, Wu IH, Zhang J, Siegel C, Komarnitsky S, Yew NS, Cheng SH: Inhibiting glycosphingolipid synthesis improves glycemic control and insulin sensitivity in animal models of type 2 diabetes. Diabetes 2007;56:1210-1218.

-63 Zigmond E, Zangen SW, Pappo O, Sklair-Levy M, Lalazar G, Zolotaryova L, Raz I, Ilan Y: Betaglycosphingolipids improve glucose intolerance and hepatic steatosis of the Cohen diabetic rat. Am J Physiol Endocrinol Metab 2009;296:E72-E78.

64 Holland WL, Summers SA: Sphingolipids, insulin resistance, and metabolic disease: new insights from in vivo manipulation of sphingolipid metabolism. Endocr Rev 2008;29:381-402.

-65 Ghashghaeinia M, Cluitmans JC, Akel A, Dreischer P, Toulany M, Koberle M, Skabytska Y, Saki M, Biedermann T, Duszenko M, Lang F, Wieder T, Bosman GJ: The impact of erythrocyte age on eryptosis. Br J Haematol 2012;157:606-614.

66 Felder KM, Hoelzle K, Ritzmann M, Kilchling T, Schiele D, Heinritzi K, Groebel K, Hoelzle LE: Hemotrophic mycoplasmas induce programmed cell death in red blood cells. Cell Physiol Biochem 2011;27:557-564. 


\section{Cellular Physiology $\quad$ Cell Physiol Biochem 2012;30:1072-1082 and Biochemistry

67 Gatidis S, Zelenak C, Fajol A, Lang E, Jilani K, Michael D, Qadri SM, Lang F: p38 MAPK Activation and Function following Osmotic Shock of Erythrocytes. Cell Physiol Biochem 2011;28:1279-1286.

68 Ghashghaeinia M, Toulany M, Saki M, Bobbala D, Fehrenbacher B, Rupec R, Rodemann HP, Ghoreschi K, Rocken M, Schaller M, Lang F, Wieder T: The NFкB Pathway Inhibitors Bay 11-7082 and Parthenolide Induce Programmed Cell Death in Anucleated Erythrocytes. Cell Physiol Biochem 2011;27:45-54.

69 Lang E, Jilani K, Zelenak C, Pasham V, Bobbala D, Qadri SM, Lang F: Stimulation of suicidal erythrocyte death by benzethonium. Cell Physiol Biochem 2011;28:347-354.

70 Nguyen DB, Wagner-Britz L, Maia S, Steffen P, Wagner C, Kaestner L, Bernhardt I: Regulation of phosphatidylserine exposure in red blood cells. Cell Physiol Biochem 2011;28:847-856.

-71 Qadri SM, Kucherenko Y, Zelenak C, Jilani K, Lang E, Lang F: Dicoumarol Activates Ca-permeable Cation Channels Triggering Erythrocyte Cell Membrane Scrambling. Cell Physiol Biochem 2011;28:857-864.

72 Qadri SM, Bauer J, Zelenak C, Mahmud H, Kucherenko Y, Lee SH, Ferlinz K, Lang F: Sphingosine but not sphingosine-1-phosphate stimulates suicidal erythrocyte death. Cell Physiol Biochem 2011;28:339-346.

73 Bhavsar SK, Eberhard M, Bobbala D, Lang F: Monensin induced suicidal erythrocyte death. Cell Physiol Biochem 2010;25:745-752.

74 Braun M, Foller M, Gulbins E, Lang F: Eryptosis triggered by bismuth. Biometals 2009;22:453-460.

75 Eberhard M, Ferlinz K, Alizzi K, Cacciato PM, Faggio C, Foller M, Lang F: FTY720-induced suicidal erythrocyte death. Cell Physiol Biochem 2010;26:761-766.

-76 Calderon-Salinas JV, Munoz-Reyes EG, Guerrero-Romero JF, Rodriguez-Moran M, Bracho-Riquelme RL, Carrera-Gracia MA, Quintanar-Escorza MA: Eryptosis and oxidative damage in type 2 diabetic mellitus patients with chronic kidney disease. Mol Cell Biochem 2011; 357:171-179.

-77 Nicolay JP, Schneider J, Niemoeller OM, Artunc F, Portero-Otin M, Haik G Jr, Thornalley PJ, Schleicher E, Wieder T, Lang F: Stimulation of suicidal erythrocyte death by methylglyoxal. Cell Physiol Biochem 2006;18:223-232.

-78 Myssina S, Huber SM, Birka C, Lang PA, Lang KS, Friedrich B, Risler T, Wieder T, Lang F: Inhibition of erythrocyte cation channels by erythropoietin. J Am Soc Nephrol 2003;14:2750-2757.

79 Lang PA, Beringer O, Nicolay JP, Amon O, Kempe DS, Hermle T, Attanasio P, Akel A, Schafer R, Friedrich B, Risler T, Baur M, Olbricht CJ, Zimmerhackl LB, Zipfel PF, Wieder T, Lang F: Suicidal death of erythrocytes in recurrent hemolytic uremic syndrome. J Mol Med 2006;84:378-388.

-80 Kempe DS, Akel A, Lang PA, Hermle T, Biswas R, Muresanu J, Friedrich B, Dreischer P, Wolz C, Schumacher U, Peschel A, Gotz F, Doring G, Wieder T, Gulbins E, Lang F: Suicidal erythrocyte death in sepsis. J Mol Med 2007;85:273-281.

81 Lang PA, Kasinathan RS, Brand VB, Duranton C, Lang C, Koka S, Shumilina E, Kempe DS, Tanneur V, Akel A, Lang KS, Foller M, Kun JF, Kremsner PG, Wesselborg S, Laufer S, Clemen CS, Herr C, Noegel AA, Wieder T, Gulbins E, Lang F, Huber SM: Accelerated clearance of Plasmodium-infected erythrocytes in sickle cell trait and annexin-A7 deficiency. Cell Physiol Biochem 2009;24:415-428.

82 Siraskar B, Ballal A, Bobbala D, Foller M, Lang F: Effect of amphotericin B on parasitemia and survival of plasmodium berghei-infected mice. Cell Physiol Biochem 2010;26:347-354.

-83 Bobbala D, Alesutan I, Foller M, Huber SM, Lang F: Effect of anandamide in Plasmodium Berghei-infected mice. Cell Physiol Biochem 2010;26:355-362.

-84 Foller M, Bobbala D, Koka S, Huber SM, Gulbins E, Lang F: Suicide for survival--death of infected erythrocytes as a host mechanism to survive malaria. Cell Physiol Biochem 2009;24:133-140.

$>85$ Koka S, Bobbala D, Lang C, Boini KM, Huber SM, Lang F: Influence of paclitaxel on parasitemia and survival of Plasmodium berghei infected mice. Cell Physiol Biochem 2009;23:191-198.

86 Kempe DS, Lang PA, Duranton C, Akel A, Lang KS, Huber SM, Wieder T, Lang F: Enhanced programmed cell death of iron-deficient erythrocytes. FASEB J 2006;20:368-370.

87 Birka C, Lang PA, Kempe DS, Hoefling L, Tanneur V, Duranton C, Nammi S, Henke G, Myssina S, Krikov M, Huber SM, Wieder T, Lang F: Enhanced susceptibility to erythrocyte «apoptosis» following phosphate depletion. Pflugers Arch 2004;448:471-477.

88 Zappulla D: Environmental stress, erythrocyte dysfunctions, inflammation, and the metabolic syndrome: adaptations to $\mathrm{CO}_{2}$ increases? J Cardiometab Syndr 2008;3:30-34. 